\title{
Prevalence of musculoskeletal conditions and related disabilities in Bangladeshi adults: a cross-sectional national survey
}

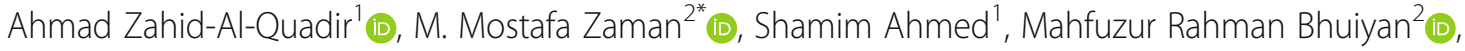 \\ Md Mujibur Rahman ${ }^{3}$ (D) Ismail Patwary ${ }^{4}$, Bidhu Bhushan Das ${ }^{5}$, Shaikh Amir Hossain ${ }^{6}$, Sujat Paul ${ }^{7}$, Abu Shahin ${ }^{8}$, \\ Moshiur Rahman ${ }^{9}$ and Syed Atiqul Haq ${ }^{1}$ (D)
}

\begin{abstract}
Background: Nationally representative data on burden of musculoskeletal conditions (MSK) in Bangladesh are not available. The objective of this study was to determine the prevalence of MSK conditions and related disabilities in the adult population of Bangladesh.

Methods: A total of 2000 individuals aged 18 years or older were targeted from 20 primary sampling units (urban and rural) of all former seven divisions of Bangladesh in 2015. Structured interviews were done using the modified Community Oriented Program for Control of Rheumatic Disorders questionnaire to detect positive respondents. Standard criteria were used for diagnosing MSK conditions by rheumatology residents. In case of uncertainty, opinion was taken from senior rheumatologists. A Bangla version of the Health Assessment Questionnaire was used to determine disability.

Results: A total of 1843 (92.1\%) participated. Among them, 892 men and 951 women participated from rural $(n=$ $716)$ and urban $(n=1127)$ areas. Their mean age was 40.5 (standard deviation 14.7) years. Almost a third did not have any formal schooling. Overall, 30.4\% (95\% confidence interval, 28.3-32.5) had MSK conditions. Low back pain $(18.6 \%, 16.9-20.5)$, knee osteoarthritis $(7.3 \%, 6.1-8.5)$ and soft tissue rheumatism 3.8\% (2.9-4.7) were the three topranking MSK conditions. Rheumatoid arthritis (1.6\%, 1.0-2.1), spondyloarthritis $(1.2 \%, 7-1.8)$ and adhesive capsulitis $(1.4 \%, 0.9-1.9)$ were relatively uncommon. Among those who had MSK conditions, 24.8\% (21.3-28.6) had some degree of disability. Of them, 24.4\% (21.0-28.1) had history of work loss during last 12 months.

Conclusions: The high burden of MSK conditions and related disabilities in Bangladesh warrants greater attention of the health system. Further studies are needed to estimate the impact of this group of conditions particularly addressing related disabilities and loss of work.
\end{abstract}

Keywords: MSK conditions, Disability, Prevalence, Bangladesh

\footnotetext{
* Correspondence: zamanm@who.int

${ }^{2}$ WHO Bangladesh, 10 Gulshan Avenue, Road Number 5, Gulshan 1, Dhaka

1212, Bangladesh

Full list of author information is available at the end of the article
}

(c) The Author(s). 2020 Open Access This article is licensed under a Creative Commons Attribution 4.0 International License, which permits use, sharing, adaptation, distribution and reproduction in any medium or format, as long as you give appropriate credit to the original author(s) and the source, provide a link to the Creative Commons licence, and indicate if changes were made. The images or other third party material in this article are included in the article's Creative Commons licence, unless indicated otherwise in a credit line to the material. If material is not included in the article's Creative Commons licence and your intended use is not permitted by statutory regulation or exceeds the permitted use, you will need to obtain permission directly from the copyright holder. To view a copy of this licence, visit http://creativecommons.org/licenses/by/4.0/ The Creative Commons Public Domain Dedication waiver (http://creativecommons.org/publicdomain/zero/1.0/) applies to the data made available in this article, unless otherwise stated in a credit line to the data. 


\section{Highlights}

1. This is the first national level study on musculoskeletal conditions using primary sampling units of Bangladesh Bureau of Statistics engaging rheumatology residents for data collection. The diagnoses have been validated or confirmed by rheumatologists in the field in partnership with divisional level medical college hospitals.

2. Prevalence of musculoskeletal conditions (low back pain, knee osteoarthritis and soft tissue rheumatism are top three conditions) is high. Their contribution to the disability and work loss makes them important to warrant public health and clinical interventions.

\section{Background}

Musculoskeletal conditions are the most common cause of severe long-term pain, physical disability and early deaths $[1,2]$. They affect hundreds of millions of people of all ages irrespective of social strata globally [3]. MSK conditions affect patients' dexterity and functions, and thereby, impact their daily life activities. The most disabling conditions are back and neck pain, osteoarthritis, rheumatoid arthritis and fractures [2]. These conditions are often associated with major non-communicable comorbidities (ischaemic heart disease, stroke, cancer and chronic respiratory disease) and they jointly augment disabilities and deaths $[4,5]$.

Pain is a common manifestation of musculoskeletal conditions. MSK is the commonest form of chronic pain for which people commonly seek medical help [6]. In addition, the MSK conditions impact quality of life [7]. These are, however, often not prioritized in the national policy making partly because these are costly and incurable [8]. Globally MSK conditions affect almost one in four adults with some regional variations. MSK conditions constitute the second cause of years lost due to disability (YLD) only after "mental and substance use disorders". Disability adjusted life years (DALYs) due to MSK were ranked ninth among 23 major conditions categorized by the World Health Organization (WHO) in 2015 [9]. The prevalence of arthritis appears to be higher in the low- and middle-income countries (LMIC) compared to higher income countries [10]. Considering the significance of MSK conditions [11, 12], WHO launched the Community Oriented Programme for Control of Rheumatic Disorders (COPCORD) in 1981. After its launch many countries in the Asia Pacific [13-25] and Latin-America $[26,27]$ completed the COPCORD surveys. Many of the COPCORD studies revealed differences in prevalence between rural and urban areas and socio-demographic conditions [14-16, 18, 21, 23, 24].
Studies in two South-Asian countries, India and Pakistan, have reported a little lower prevalence $[20,21]$ than those reported from other regions. Institute of Health Matrix data indicate that low back pain was the topmost cause disability in 2007 in Bangladesh [28]. It continued to occupy the topmost position in 2017. Other MSK conditions ranked the 4th position in 2017 rising from the 5th position in 2007. One survey in Bangladesh conducted in two locations of Dhaka district reported a prevalence of $24 \%$ of MSK conditions [23]. Bangladesh is a country of 160 million people mostly living in rural areas but data from rural areas are not available. In addition, there is no nationally representative data on these conditions. MSK-related disabilities have never been studied at population level in Bangladesh. We have done this national level survey to determine the prevalence of MSK conditions and related disabilities in Bangladeshi adult population.

\section{Methods}

This survey was designed to obtain national estimates on the burden of MSK conditions through a household level survey. Adults aged 18 years or more comprised the study population [29].

\section{Sample size and sampling}

Assuming a point prevalence of MSK conditions among Bangladeshi adults of $24 \%$ [23], at $5 \%$ precision level, 280 participants were required in each reporting domain. Considering four reporting domains (rural-urban, malefemale), a design effect of 1.5 , and an $85 \%$ response rate, the calculated sample size for this survey was 1978 . This was finally rounded to 2000 .

The primary sampling units (PSUs) in Bangladesh constitute the sampling frame of national or subnational surveys. We used the PSUs of 2001 Census stratified in to the then seven divisions and rural and urban areas [30]. Mauza and Mahalla in rural and urban areas, respectively, were the PSUs with known boundaries. Maps with list of households of these PSUs were updated by the Bangladesh Bureau of Statistics. Total and urban rural population of the division were considered for allocating number of PSUs. Finally, 20 PSUs (8 urban and 12 rural) were selected and first consecutive100 households were included from each PSU. Households having even and odd numbers were assigned as male and female households to recruit one man and one woman, respectively, using the Kish table [31].

\section{Field team and its training}

We employed seven field teams for seven divisions of Bangladesh. Each team consisted of one research physician (having at least one-year residency in rheumatology), one field organizer and two interviewers. The field 
team underwent a three-day training in Bangabandhu Sheikh Mujib Medical University before the pretest. All investigators and WHO technical team coordinated and conducted the training using a manual especially prepared for this survey. All investigators were present at the training sessions to ensure uniform understanding of procedures. After completion of the pretest, all investigators and the field had a one-day debriefing session for revising the manual and adjustment of the data collection tool. Another one-day refreshers training was done after completing one PSU by each team to minimize differences among teams.

\section{Survey instrument and data collection}

The survey instrument was the modified COPCORD questionnaire [32]. The first part of the questionnaire aimed at detecting the respondents with musculoskeletal pain with some elaboration of the complaints. This portion was completed by the interviewers. The second part of the questionnaire had structured information for recording subjects' history and clinical examination findings according to the COPCORD examination sheet. This was used by the research physicians for the diagnosis of conditions and detection of disability. The English version of the first part (that has been administered by the interviewers) of the questionnaire was translated to Bangla, then adapted and validated as per standard procedure [33].

\section{Field work}

Data were collected in each PSU over a period of 6 days with engagement of the local community and health authority. The field organizer visited in advance and started household listing with the help of local health assistant on the first day. The field interviewers collected data (by reading out questions loudly to all participants), identified screening positive respondents, took physical measurements, and arranged interview with the research physician next 5 days. Two recall visits were done if the selected house was locked, selected person was not at home at the time of interviewer's visit. They were declared non-respondents in case interview could not be done at the second recall. The research physician interviewed and examined the positive respondents for making a diagnosis. In doubtful cases, opinion of a division level investigator was taken. Investigators made at least one visit to PSUs in their respective divisions for validation of diagnosis. Erythrocyte sedimentation rate, Creactive protein, rheumatoid factor and anti-citrullinated peptide antibody were tested in a pre-selected laboratory located nearby to aid the diagnosis. X-rays were also done as and when necessary.

\section{Operational definitions \\ Covariates}

The following variables were assessed as covariates for analysis: area of residence, sex, age, education, occupation, wealth index, body mass index (BMI). Education was categorized into four groups: no education, any primary education (completed grades $1-5$ ), any secondary education (completed grades 6-10), and above secondary education (completed $\geq$ grade 11). Participants' occupation was categorized into seven groups: home makers, laborers, business, salaried services, rickshaw/ auto-rickshaw/van pullers, cultivators and others.

The wealth index was constructed using principal component analysis [29]. Asset information collected covered information on household ownership of 20 items, such as flush toilet, telephone, television, bicycle, sewing machine, bed. Each asset was assigned a weight (factor score) generated through principal components analysis. The scores were summed up for each household, individuals were ranked according to the total score of their households. The sample was then divided into four hierarchical groups from quartile one (lowest) to quartile four (highest).

Data on physical activity were collected based on selfreport. First, respondents were asked the number of days they engaged in vigorous, moderate, or light physical activity throughout a typical week. Examples of vigorous, moderate and light activity were shown to the participants using showcards. Next, they were asked to estimate how many minutes per day they engaged in the activity. We then calculated metabolic equivalent tasks (MET)-minutes per week using the STEPwise Surveillance of noncommunicable disease risk factors (STEPS) protocol [29]. Finally, quintiles of MET-minutes were created, and the highest quintile was labelled as strenuous physical activity. Smoking habit was asked and recorded as current smoker, former smoker and nonsmoker of any tobacco product such as cigarette, bidi and hukkah (water pipe).

History of physical trauma during last 12 months that needed medical treatment with or without residual damage, e.g., injuries due to accidents while travelling by road, trauma during occupational works while working in farming lands or factories, physical assault, etc., were obtained. Using height (meters) and weight (kilograms) measurements, we calculated BMI (weight/height ${ }^{2}$ ). People having $\mathrm{BMI} \geq 25.0$ were labelled as over-weight (this includes obese also). Random capillary blood glucose was measured. Diabetes was defined as blood glucose $\geq 11.1$ or use of antidiabetic medication.

\section{Positive respondent}

A subject was considered a positive respondent if he/she reported occurrence of pain at muscles, bones, joints, or 
any part of the body (musculoskeletal symptom) during the preceding 7 days. Subjects who did not report pain on those 7 days but were taking prescribed medicines for relieving pain, e.g., non-steroidal anti-inflammatory drugs or steroids, were also included. The respondents in whom musculoskeletal pain appeared, developed, or disappeared in the preceding 7 days were also labeled as a positive respondent.

\section{MSK conditions}

All positive respondents were interviewed and thoroughly examined by the research physicians. Internationally accepted criteria [34-38] were used with adaptations whenever necessary. For conditions with no internationally accepted criteria and epidemiological definition, the clinical judgment of the research physician was used. In case uncertainty, opinion was taken from the investigators during their routine visit to respective PSUs. Following criteria were used for diagnosis of the MSK conditions:

1. Rheumatoid arthritis: 2010 American College of Rheumatology (ACR)/European League Against Rheumatism (EULAR) Classification Criteria [39];

2. Spondyloarthritis (axial and peripheral): Ankylosing Spondylitis Assessment Study (ASAS) criteria [40];

3. Ankysosing spondylitis: Modified New York Criteria 1984 [41];

4. Psoriatic arthritis: Classification Criteria for Psoriatic Arthritis (CASPAR) criteria [42];

5. Knee osteoarthritis: ACR clinical classification criteria for knee osteoarthritis (OA) [43];

6. Systemic Lupus Erythematosus: ACR Revised Criteria for the Classification of Systemic Lupus Erythematosus 1997 Systemic Lupus Erythematosus [44];

7. Soft tissue rheumatism: Commonly included subacromial bursitis, epicondylitis, trochanteric bursitis, anserine bursitis, and fibromyalgia [45];

Considering the limitations of investigations in the field situation, the differentiation between non-specific low back pain and lumbar spondylosis was not possible in many cases. Therefore, we have pooled these two together to report he prevalence. These are reported as low back pain.

\section{Disability and work loss}

Disability was scored with a validated Bangla version of the Health Assessment Questionnaire (B-HAQ) [46]. This tool assesses the subjects' level of functional ability and included questions of fine movements of the upper extremity, locomotor activities of the lower extremity, and activities that involve extremities. The B-HAQ included 20 items referring to basic activities of daily living, grouped into eight categories of functioning, viz., dressing and grooming, arising, eating, walking, hygiene, reach, grip and activities. Each category contained two or three specific component questions. Respondents are asked to rate the degree of difficulty they experienced in carrying out each activity on a 4-point rating scale: 0 (without any difficulty), 1 (with some difficulty), 2 (with much difficulty), and 3 (unable to do). The highest response in each category was divided by 8 to create a BHAQ Disability index (B-HAQ-DI), yielding a total disability score of $0-3$, where zero is no disability and 3 is severe disability [47]. Any one scoring $\geq 0.8$ for B-HAQDI was categorized as having disability according to Quintana R et al. [48].

The recall period for determining work loss was 12 months. We have asked the participants whether they had to stop their usual occupational work, paid or unpaid (such as home makers), due to MSK conditions or related pain. Then the duration of such work loss (in days) was asked and recorded

\section{Statistical analysis}

The data were entered into Excel spreadsheet and transferred to EpiInfo (version 7) for analysis. Missing values were identified to confirm the denominators, and consistency were checked.

All quantitative variables such as age, years of education, body mass index (BMI), B-HAQ-DI score were categorized before analysis. Alfa was set at $5 \%$ for considering statistical significance. Therefore 95\% confidence intervals (CI) were calculated for all prevalence estimates such as MSK conditions, disabilities and related work loss. Results were presented for four reporting domains: rural and urban residential locations, and sex groups. Univariate logistic regression analysis was done for 11 candidate variables (age, sex, education, wealth quartiles, urban residence, smoking, strenuous physical activity, occupation, overweight, history of physical trauma, and diabetes) to get odds ratios (ORs) with their 95\% CIs for MSK conditions combined (yes/no). Tri-variate logistic regression analysis was done for nine candidate variables (education, wealth quartiles, urban residence, smoking, strenuous physical activity, occupation, over-weight, history of physical trauma, and diabetes) to obtain age and sex adjusted odds ratios and their 95\% confidence intervals of MSK conditions combined.

\section{Ethics approval and consent to participate}

Ethical guidelines as outlined by the Declaration of Helsinki were followed throughout the study [49]. Ethical clearance was obtained from the Institutional Review Board of Bangabandhu Sheikh Mujib Medical University. Concurrence has been obtained from the local health authorities and elected representatives of the local 
government prior to data collection. Written (or thumb impression if unable to write) consent was obtained from the respondents in Bangla as per Institutional Review Board guidelines.

\section{Results}

Socio-demographic background

A total of 1843 respondents (aged 18 years or older) could be interviewed and examined out of targeted 2000 (response rate of 92.2\%) as depicted in Fig. 1. The response rate was a little higher in the rural $(93.9 \%)$ compared to the urban area (89.5\%). There were 892 (48.4\%) men and 951 (51.6\%) women respondents. Mean age of the participants was 40.5 (standard deviation 14.7) years. Background data are presented in Table 1 . Nearly 3 in 10 did not have any formal schooling. Although the occupation of men was diverse, almost 8 in 10 women were home makers. One in 5 men were from occupational categories of day-labourer (23.4\%), business (20.3\%), and cultivation (18.9\%). One in $5(21.3 \%)$ were overweight or obese $\left(\mathrm{BMI}>=25.0 \mathrm{~kg} / \mathrm{meter}^{2}\right)$.

\section{MSK conditions}

There were 561 people with rheumatic conditions (225 men and 336 women). Prevalence of any MSK disorder was $30.4 \%$ with $95 \%$ confidence interval (CI) 28.3-32.5,

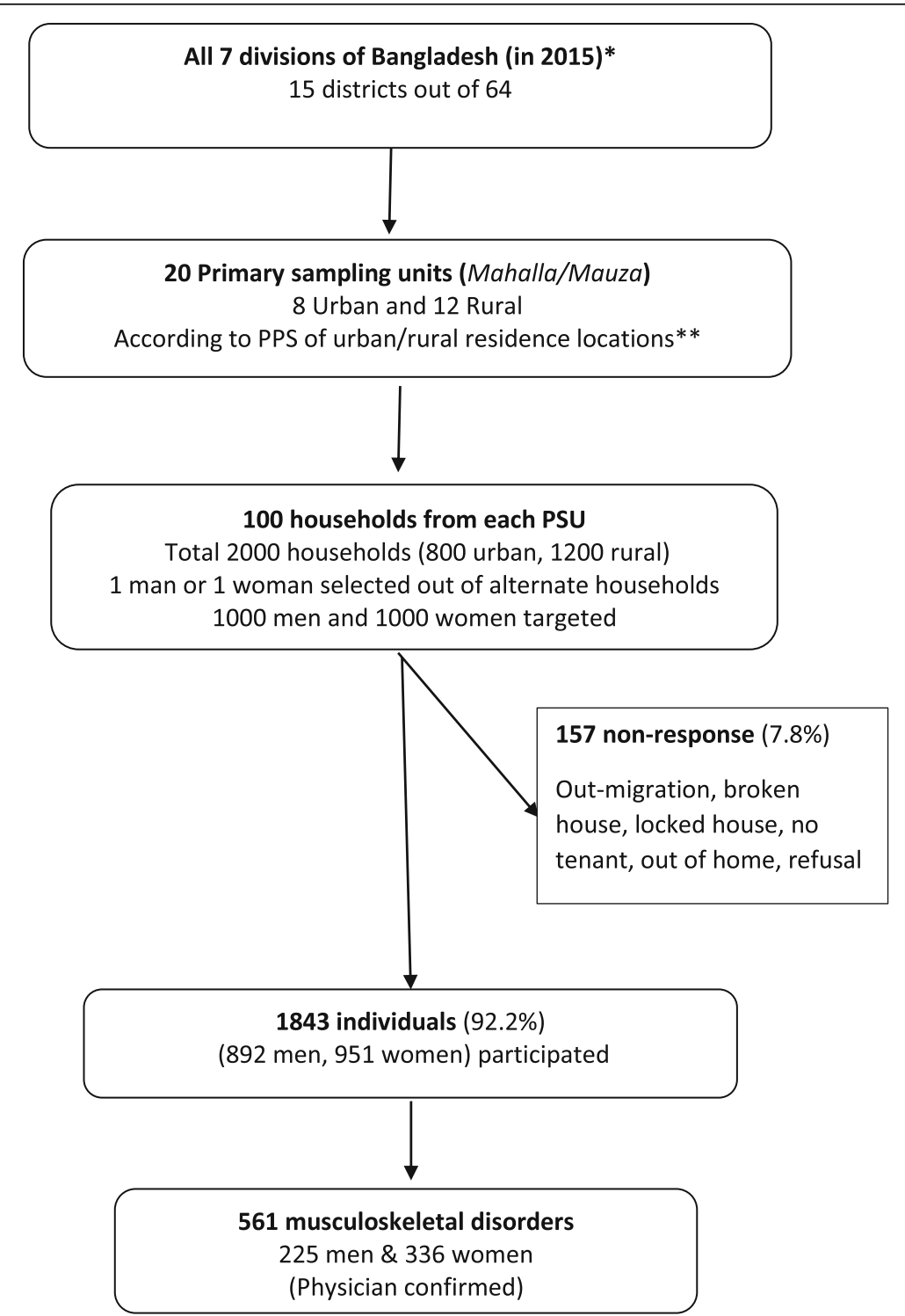

Fig. 1 Flowchart for subject selection of the cross-sectional national survey on musculoskeletal conditions in Bangladesh, 2015. *Eight divisions from Sept 2015. PPS indicates population proportion to size.

**Two recall visits were done if the selected house was locked, and selected person was not available at home at the time of interviewer's visit. In case of non-particiaption after the second recall visit, the targeted household/individual was declared non-respondents 
Table 1 Social and other risk factors (number, percent) in adults, cross-sectional national survey in Bangladesh, 2015

\begin{tabular}{|c|c|c|c|c|c|}
\hline Risk factors & $\begin{array}{l}\text { Urban } \\
(n=716)\end{array}$ & $\begin{array}{l}\text { Rural } \\
(n=1127)\end{array}$ & $\begin{array}{l}\text { Men } \\
(n=892)\end{array}$ & $\begin{array}{l}\text { Women } \\
(n=951)\end{array}$ & $\begin{array}{l}\text { All } \\
(n=1843)\end{array}$ \\
\hline \multicolumn{6}{|l|}{ Age, years } \\
\hline $18-34$ & $296(41.3)$ & $415(36.8)$ & $217(24.3)$ & $494(51.9)$ & 711 (38.6) \\
\hline $35-54$ & $306(42.7)$ & $468(41.5)$ & $422(47.3)$ & $352(37.0)$ & $774(42.0)$ \\
\hline $55-99$ & $114(15.9)$ & $244(21.7)$ & $253(28.4)$ & $105(11.0)$ & $358(19.4)$ \\
\hline \multicolumn{6}{|l|}{ Occupation } \\
\hline Homemakers & $254(35.5)$ & $495(43.9)$ & $0(0.0)$ & 749 (78.8) & $749(40.7)$ \\
\hline Laborer & $81(11.3)$ & $161(14.3)$ & $209(23.4)$ & $33(3.5)$ & $242(13.1)$ \\
\hline Business professional & $111(15.5)$ & $75(6.7)$ & $181(20.3)$ & $5(0.5)$ & $186(10.1)$ \\
\hline Service holder & $96(13.4)$ & $29(2.6)$ & $98(11.0)$ & $27(2.8)$ & $125(6.8)$ \\
\hline Rickshaw/ Auto-Rick/Van puller & $27(3.8)$ & $44(3.9)$ & $70(7.9)$ & $1(0.1)$ & $71(3.8)$ \\
\hline Cultivator & $5(0.7)$ & $164(14.6)$ & $168(18.9)$ & $1(0.1)$ & $169(9.2)$ \\
\hline Others & $142(19.8)$ & $159(14.1)$ & $166(18.6)$ & $135(14.2)$ & $301(16.3)$ \\
\hline \multicolumn{6}{|l|}{ Education level } \\
\hline No formal education (0) & $143(20.0)$ & $421(37.4)$ & $267(29.9)$ & $297(31.2)$ & $564(30.6)$ \\
\hline Any primary education $(1-5)$ & $131(18.3)$ & $325(28.8)$ & $233(26.1)$ & $223(23.4)$ & $456(24.7)$ \\
\hline Any secondary education (6-10) & $232(32.4)$ & $306(27.2)$ & $246(27.6)$ & $292(30.7)$ & $538(29.2)$ \\
\hline Above secondary $(>=11)$ & $210(29.3)$ & $75(6.7)$ & $146(16.4)$ & $139(14.6)$ & $285(15.5)$ \\
\hline \multicolumn{6}{|l|}{ Wealth index quartiles ${ }^{a}$} \\
\hline $1 \mathrm{st}$ & $75(10.5)$ & $401(35.6)$ & $206(23.1)$ & $270(28.4)$ & $476(25.8)$ \\
\hline 2nd & $108(15.1)$ & $354(31.4)$ & $220(24.7)$ & $220(25.4)$ & $462(25.1)$ \\
\hline $3 r d$ & $203(28.4)$ & $245(21.7)$ & $231(25.9)$ & $217(22.8)$ & $448(24.3)$ \\
\hline 4 th & $330(46.1)$ & $127(11.3)$ & $235(26.3)$ & $222(23.3)$ & $457(24.8)$ \\
\hline Overweight (body mass index $\geq 25 \mathrm{Kg} / \mathrm{m}^{2}$ ) & $225(31.4)$ & $167(14.8)$ & $148(16.6)$ & $244(25.7)$ & $392(21.3)$ \\
\hline History of physical trauma ${ }^{b}$ & $78(10.9)$ & $100(8.9)$ & $88(9.9)$ & $90(9.5)$ & $178(9.7)$ \\
\hline Smoking, ever & $207(28.9)$ & $392(34.9)$ & $583(65.4)$ & $16(1.7)$ & $599(32.5)$ \\
\hline Diabetes mellitus $^{\complement}$ & $73(10.2)$ & $36(3.2)$ & $50(5.6)$ & $59(6.2)$ & $109(5.9)$ \\
\hline Strenuous physical activity ${ }^{d}$ & $124(17.3)$ & $230(20.4)$ & $336(37.7)$ & $18(1.9)$ & $354(19.2)$ \\
\hline
\end{tabular}

${ }^{a}$ The wealth index was constructed using principal component analysis out of a list of 20 household assets (See Methods section for details);

${ }^{b}$ Physical trauma during last 12 months that needed medical treatment with or without residual damage, e.g., injuries due to accidents while travelling by road, trauma during occupational works while working in farming lands or factories, physical assault, etc.;

'Diabetes was defined as random capillary glucose level > =11.1 or medication for diabetes;

${ }^{d}$ Fifth quintile of the MET-minutes distribution of work-related physical activity. Commutation and leisure time physical activities were not considered because these were negligible contributors (See Methods section for details)

which was higher in women $(35.3 \%, 32.3-38.4)$ compared to men $(25.2 \%, 22.4-28.1)$ (Table 2). Low back pain including lumbar spondylosis $(18.6 \%)$ and knee osteoarthritis (7.3\%), and soft tissue rheumatism (3.8\%) were the commonest conditions in sexes combined. The prevalence of rheumatoid arthritis was $1.6 \%$. Among all conditions, low back pain and rheumatoid arthritis differed significantly between men and women. The gender difference for soft tissue rheumatism showed a borderline significance, 95\% CI being 1.5-3.6 for men and 3.66.3 for women. Others were not significantly different as indicated by overlapping 95\% confidence intervals.

The prevalence of MSK in general increased with age, but it was inversely related to educational and economic status
(Fig. 2). However, this relationship is very subtle in case of economic achievements. Certain occupations (such as home maker, cultivator and manual vehicle puller) had higher rates, but these differences were not statistically significant. Overall prevalence did not differ significantly between rural (31.1\%, 28.4-33.8) and urban areas (29.5\%, 26.1-32.8\%). This was true for specific conditions also (Fig. 3).

\section{Musculoskeletal pain}

One-third men and women had musculoskeletal pain, although determined subjectively, and $9.1 \%$ of them had very severe pain. Low back (20.2\%), knee (12.2\%) and shoulder (6.2\%) joints were the commonest site of pain. Next common sites were elbow (4.9\%) and wrist (4.3\%) joints (Table 3). We 
Table 2 Prevalence and 95\% confidence interval (Cl) of musculoskeletal conditions in adults, cross-sectional national survey in Bangladesh, 2015

\begin{tabular}{|c|c|c|c|c|c|c|c|c|c|}
\hline \multirow{2}{*}{$\begin{array}{l}\text { Rheumatic } \\
\text { Disorders }\end{array}$} & \multicolumn{3}{|c|}{ Men $(n=892)$} & \multicolumn{3}{|c|}{ Women $(n=951)$} & \multicolumn{3}{|c|}{ Both Sexes $(n=1843)^{a}$} \\
\hline & $\mathbf{n}$ & $\%$ & $95 \% \mathrm{Cl}$ & $\mathbf{n}$ & $\%$ & $95 \% \mathrm{Cl}$ & $\mathbf{n}$ & $\%$ & $95 \% \mathrm{Cl}$ \\
\hline Rheumatoid arthritis & 6 & 0.7 & $0.1-1.2$ & 23 & 2.4 & $1.4-3.4$ & 29 & 1.6 & $1.1-2.3$ \\
\hline Spondyloarthropathy & 13 & 1.5 & $0.7-2.2$ & 10 & 1.1 & $0.4-1.7$ & 23 & 1.3 & $0.8-1.9$ \\
\hline Knee osteoarthritis & 60 & 6.7 & $5.1-8.4$ & 74 & 7.8 & $6.1-9.5$ & 134 & 7.3 & $6.2-8.6$ \\
\hline Low back pain ${ }^{\mathrm{b}}$ & 126 & 14.1 & $12.1-16.7$ & 217 & 22.8 & $20.3-25.6$ & 343 & 18.6 & 16.9-20.5 \\
\hline Cervical spondylosis & 14 & 1.6 & $0.8-2.4$ & 11 & 1.2 & $0.5-1.8$ & 25 & 1.4 & $0.8-1.9$ \\
\hline Soft tissue rheumatism ${ }^{c}$ & 23 & 2.6 & $1.5-3.6$ & 47 & 4.9 & $3.6-6.3$ & 70 & 3.8 & $3.0-4.8$ \\
\hline Adhesive capsulitis of shoulder joint & 10 & 1.1 & $0.4-1.8$ & 16 & 1.7 & $0.9-2.5$ & 26 & 1.4 & $1.0-2.1$ \\
\hline Connective tissue disorder & 1 & 0.1 & $0-0.3$ & 5 & 0.5 & $0.1-1.0$ & 6 & 0.3 & $0.2-0.7$ \\
\hline Other noninflammatory ${ }^{d}$ & 31 & 3.5 & $2.3-4.7$ & 31 & 3.3 & $2.1-4.4$ & 62 & 3.4 & $2.6-4.3$ \\
\hline Other inflammatory ${ }^{\mathrm{e}}$ & 7 & 0.8 & $0.2-1.4$ & 14 & 1.5 & $0.7-2.2$ & 21 & 1.1 & $0.8-1.7$ \\
\hline Any rheumatic disorder & 225 & 25.2 & $22.4-28.1$ & 336 & 35.3 & $32.3-38.4$ & 561 & 30.4 & $28.3-32.5$ \\
\hline
\end{tabular}

Prevalence shown in bold face having non-overlapping $\mathrm{Cls}$ are significantly different $(P<0.05)$ between sexes;

a Multiple diagnosis in 192 patients. Therefore, the total of diseases exceeds 561;

${ }^{\mathrm{b}}$ This category includes lumbar spondylosis also because accurate differentiation was not feasible in the field situation, investigation facility, etc.;

'This includes subacromial bursitis, epicondylitis, trochanteric bursitis, anserine bursitis, and fibromyalgia;

${ }^{\mathrm{d} O s t e o a r t h r i t i s ~ o f ~ h i p, ~ o s t e o a r t h r i t i s ~ o f ~ h a n d s, ~ t r a u m a t i c ~ a r t h r i t i s, ~ t r a u m a t i c ~ f r a c t u r e ~ r e l a t e d ~ c o n d i t i o n, ~ t r a u m a ~ o f ~ l i g a m e n t s ~ a n d ~ s o f t ~ i s s u e, ~ v a g u e ~ s y m p t o m s ~ o f ~}$ myalgia and muscle spasm, vertebral spine related sciatica, vertebral scoliosis, ill-defined rheumatic syndromes;

'Monoarthritis, oligoarthritis, polyarthritis, gout, palindromic rheumatism, adult Still's disease, vasculitis, primary Sjogren syndrome

did not observe substantial difference in distribution of pain sites between rural and urban areas.

\section{Disability and work loss}

People with MSK conditions had a mean B-HAQ-DI score of 0.63 . One-quarter $(24.8 \%, 21.3-28.6)$ had some or much difficulty in doing their daily works defined by B-HAQ-DI score $\geq 0.8$ (Table 4). None were in the 'unable to do' (B-HAQ score, 3.0) category. Their proportions were statistically similar between men (19.1\%, 24.2-24.9) and women (28.6\%, 23.9-33.8) with overlapping confidence intervals. The prevalence has shown an

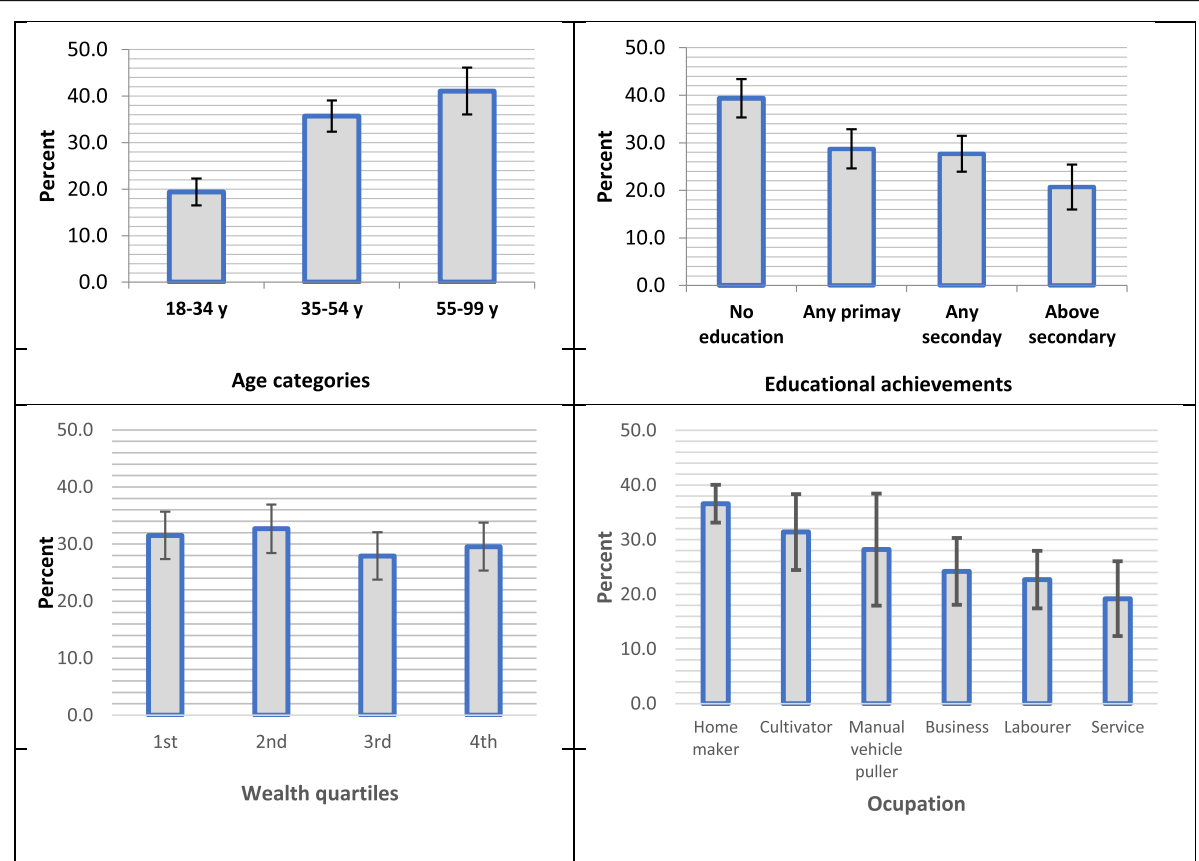

Fig. 2 Prevalence of musculoskeletal conditions in adults according to age, educational achievement, economic status* and occupation, national cross-sectional survey in Bangladesh, 2015.

*Wealth quartiles were created using household assets using principle component analysis 


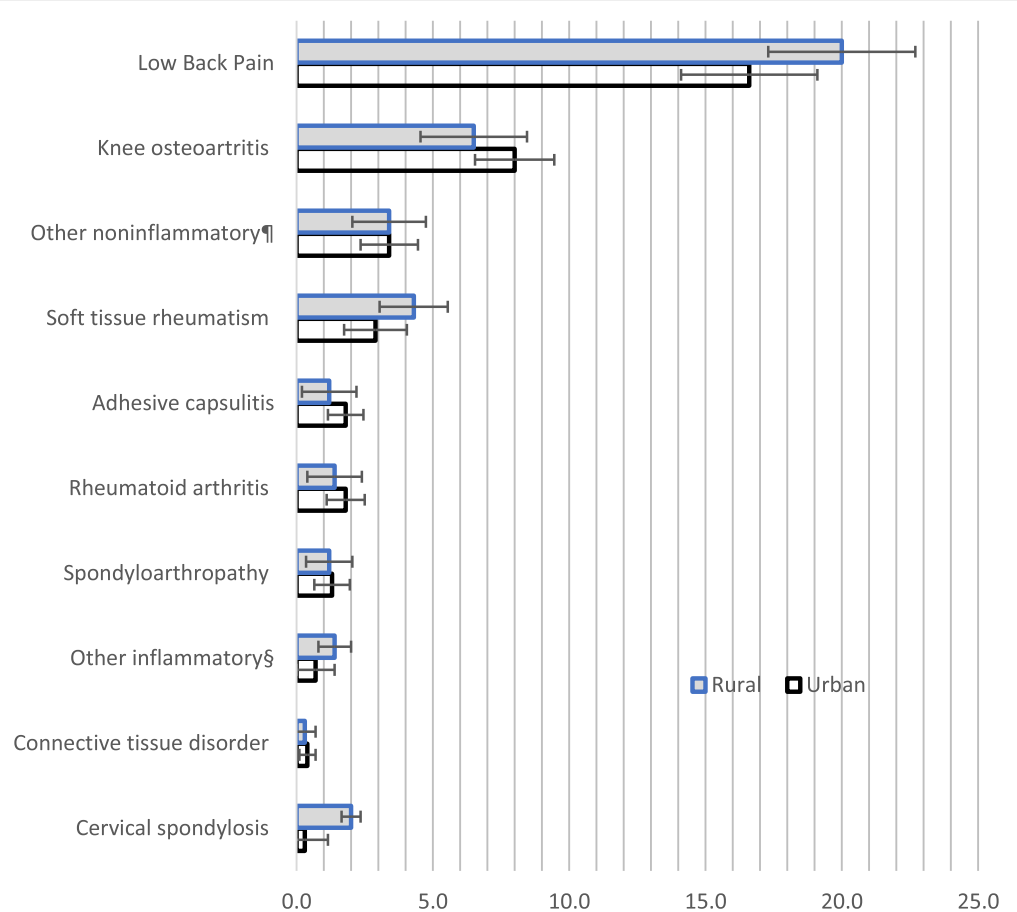

Fig. 3 Prevalence of musculoskeletal conditions in adults according to urban-rural residence locations, cross-sectional national survey in Bangladesh, 2015.

Sincludes osteoarthritis of hip, osteoarthritis of hand, traumatic arthritis, traumatic fracture related condition, trauma of ligament and soft issue, vague symptoms of myalgia and muscle spasm, vertebral spine related sciatica, vertebral scoliosis, ill-defined rheumatic syndromes;

Iincludes monoarthritis, oligoarthritis, polyarthritis, gout, palindromic rheumatism

increasing trend with age, $14.9 \%$ in $18-34$ years age group to $36.6 \%$ in $55+$ year age group. Among the eight domains of B-HAQ-DI, the commonest problems were with daily works, walking and arising. Of those who had disability, $24.4 \%(21.0,28.1)$ had work loss during last 12 months. Work loss in men (27.1\%) and women (22.6\%) was similar as indicated by overlapping confidence intervals. They had 12 median days of work loss during those 12 months.

\section{Factors associated with MSK conditions}

Univariate logistic regression found significant relationship of six out of 11 candidate variables. These are age, education, smoking, strenuous physical activity, occupation, physical trauma, overweight and diabetes) as none of the 95\% CIs of odds ratios included null values. However, in trivariate logistic regression analysis adjusted for age and sex, the significant relationship of education (odds ratio, 0.9, 0.8-0.9), overweight $(1.5,1.2-1.9)$, trauma $(1.9,1.4-2.6)$ and diabetes $(1.5,1.0-2.2)$ persisted (Table 5). All other odds ratios became attenuated upon adjustment.

\section{Discussion}

MSK conditions are among the most relevant health issues worldwide owing to the human suffering they impose, in addition to their increasing social and economic costs $[50,51]$. In spite of the available evidence, MSK conditions are under-addressed in terms of programmatic approaches, treatment and health system's response. We report here for the first time a nationally representative study in Bangladeshi adults addressing the equity issues related to age, sex and socio-economic status. We report here that three in ten Bangladeshi adults suffer from MSK conditions, and among them one in four has varying degrees of disability.

\section{Musculoskeletal pain}

Pain was the commonest manifestation. Our survey questions were whether the respondents had pain, swelling and stiffness. Almost all 551 out of 561 had pain. Although remaning 10 subjects did not report pain, presence of pain could not be ruled out with certainty. They started taking NSAIDs or steroids advised by their doctors and continued taking these medicines overlapping our recall period of 7 days. Like our previous survey [23], we observed an increased frequency of pain with age. Women had higher frequency of pain compared to men, as was reported by most of the researchers. Similarly, the prevalence of musculoskeletal pain was greater in rural areas compared to urban areas. Commonest 
Table 3 Common musculoskeletal pain sites in adults, cross-sectional national survey in Bangladesh, 2015

\begin{tabular}{|c|c|c|c|c|c|c|}
\hline \multirow[t]{2}{*}{ Pain location } & \multicolumn{2}{|c|}{ Urban $(n=716)$} & \multicolumn{2}{|c|}{ Rural ( $n=1127)$} & \multicolumn{2}{|c|}{ Both $(n=1843)$} \\
\hline & $\%$ & $95 \% \mathrm{Cl}^{\mathrm{a}}$ & $\%$ & $95 \% \mathrm{Cl}^{\mathrm{a}}$ & $\%$ & $95 \% \mathrm{Cl}^{\mathrm{a}}$ \\
\hline Whole body pain & 1.0 & $0.3-1.7$ & 1.4 & $0.7-2.1$ & 1.2 & $0.7-1.7$ \\
\hline Shoulder joint & 5.0 & $3.4-6.6$ & 6.9 & $5.4-8.4$ & 6.2 & $5.1-7.3$ \\
\hline Elbow joint & 2.5 & $1.4-3.6$ & 6.5 & $5.1-7.9$ & 4.9 & $3.9-5.9$ \\
\hline Wrist joint & 3.1 & $1.8-4.4$ & 5.1 & $3.8-6.4$ & 4.3 & $3.4-5.2$ \\
\hline Hand joints & 3.4 & $2.1-4.7$ & 4.3 & $3.1-5.5$ & 4.0 & $3.1-4.9$ \\
\hline Hip joint & 0.7 & $0.1-1.3$ & 0.8 & $0.3-1.3$ & 0.8 & $0.4-1.2$ \\
\hline Knee joint & 10.6 & $8.3-12.9$ & 13.2 & $11.2-15.2$ & 12.2 & $10.7-13.7$ \\
\hline Ankle joint & 2.8 & $1.6-4.0$ & 4.1 & $2.9-5.3$ & 3.6 & $2.7-4.5$ \\
\hline Foot joint & 2.2 & $1.1-3.3$ & 2.6 & $1.7-3.5$ & 4.9 & $3.9-5.9$ \\
\hline Neck & 3.1 & $1.8-4.4$ & 3.4 & $2.3-4.5$ & 3.3 & $2.5-4.1$ \\
\hline Upper back & 4.3 & $2.8-5.8$ & 3.2 & $2.2-4.2$ & 3.6 & $2.7-4.5$ \\
\hline Lower back & 17.3 & $14.5-20.1$ & 22.0 & $19.6-24.4$ & 20.2 & $18.4-22$ \\
\hline Chest & 1.1 & $0.3-1.9$ & 1.7 & $0.9-2.5$ & 1.5 & $0.9-2.1$ \\
\hline Arm & 1.5 & $0.6-2.4$ & 1.8 & $1.0-2.6$ & 1.7 & $1.1-2.3$ \\
\hline Forearm & 1.0 & $0.3-1.7$ & 2.5 & $1.6-3.4$ & 1.9 & $1.3-2.5$ \\
\hline Hand & 1.4 & $0.5-2.3$ & 2.0 & $1.2-2.8$ & 1.8 & $1.2-2.4$ \\
\hline Hip & 0.7 & $0.1-1.3$ & 0.3 & $0-0.6$ & 0.4 & $0.1-0.7$ \\
\hline Thigh & 1.1 & $0.3-1.9$ & 2.9 & $1.9-3.9$ & 2.2 & $1.5-2.9$ \\
\hline Leg & 4.3 & $2.8-5.8$ & 3.8 & $2.7-4.9$ & 4.0 & $3.1-4.9$ \\
\hline Foot & 1.1 & $0.3-1.9$ & 2.1 & $1.3-2.9$ & 1.7 & $1.1-2.3$ \\
\hline
\end{tabular}

Percent figures shown in bold face having non-overlapping $\mathrm{Cls}$ are significantly different $(P<0.05)$ between urban-rural areas of residence; ${ }^{\mathrm{a}} \mathrm{Cl}$ indicates confidence interval

sites were low back (20.2\%), knees and shoulders as in most other COPCORD studies including ours [23], except in India [21] and Iran [52]. There are many factors for high rates of low back pain. The most frequently reported factors are heavy physical workload such as lifting, awkward posture, lack of exercise and obesity [53] and age (especially above 35 years) [54]. Unidentified causes of high prevalence of low back pain in developing country may be vitamin D deficiency due to limited sun exposure and multiparity [55].

\section{MSK conditions}

The most common MSK disorder in the study was low back pain (18.6\%). The prevalence of low back pain was nearly like that of India [21], Kuwait [56] and Malaysia [57] but lower than in rural Iran [24] and urban Indonesia [15]. There are reports of higher prevalence of low back pain in occupations involving postural changes and weight-lifting [58-60]. The social culture of domestic and professional activities in bending posture may be responsible for higher prevalence of low back pain in Bangladesh but it needs further in-depth scrutiny. A

Table 4 Disability and work loss among subjects with musculoskeletal conditions, cross-sectional national survey in Bangladesh, $2015^{a}$

\begin{tabular}{|c|c|c|c|}
\hline Disability indices & Men $(n=225)$ & Women $(n=336)$ & Both, $(n=561)$ \\
\hline B-HAQ-DI' score, mean & $0.56(0.47-0.65)$ & $0.68(0.61-0.76)$ & $0.63(0.56-0.71)$ \\
\hline Disability (B-HAQ-DI Score $\geq 0.8)^{\complement}, \%$ & $19.1(14.2-24.9)$ & $28.6(23.9-33.8)$ & $24.8(21.3-28.6)$ \\
\hline Any work loss (last 12 months), \% & $27.1(21.7-33.3)$ & $22.6(18.5-27.4)$ & $24.4(21.0-28.1)$ \\
\hline Duration of work loss (last 12 months) ${ }^{\mathrm{d}}$, mean & $14.7(6.8-22.6)$ & 9.7 (3.8-15.6) & $11.7(7.4-16.1)$ \\
\hline
\end{tabular}

${ }^{a}$ Results in the parentheses are $95 \%$ confidence intervals; None of the results are significantly different between sexes as indicated by overlapping confidence intervals:

${ }^{\mathrm{b}} \mathrm{B}-\mathrm{HAQ}-\mathrm{DI}$ indicates Bengali version of the Health Assessment Questionnaire Disability Index

'The cut-off point is according to Rosana Quintana (2016) [36]

${ }^{\mathrm{d}}$ Number of days the incumbent had to stop working because of pain and related problems 
Table 5 Results of multiple logistic regression for musculoskeletal conditions combined, cross-sectional national survey in Bangladesh, 2015

\begin{tabular}{|c|c|c|c|c|}
\hline \multirow[t]{2}{*}{ Variables } & \multirow{2}{*}{$\begin{array}{l}\text { Unadjusted } \\
\text { Odds ratio }\end{array}$} & \multirow[b]{2}{*}{$95 \%$ confidence interval } & \multicolumn{2}{|c|}{ Age and sex adjusted } \\
\hline & & & Odds ratio & 95\% confidence interval \\
\hline Age groups $^{a}$ & 1.73 & $1.51-1.99$ & & \\
\hline Sex $($ women = $2 /$ men $=1)$ & 1.62 & $1.32-1.98$ & & \\
\hline Education groups ${ }^{b}$ & 0.76 & $0.69-0.83$ & 0.87 & $0.78-0.96$ \\
\hline Wealth quartiles & 0.95 & $0.87-1.04$ & 0.98 & $0.90-1.08$ \\
\hline Urban residence & 1.08 & $0.88-1.32$ & 1.00 & $0.81-1.24$ \\
\hline Smoking, ever vs never & 1.41 & $1.13-1.75$ & 1.05 & $0.77-1.43$ \\
\hline Strenuous physical activity $^{c}$ & 0.66 & $0.51-0.86$ & 0.97 & $0.71-1.32$ \\
\hline Occupational groups ${ }^{d}$ & 0.96 & $0.92-0.99$ & 1.00 & $0.95-1.05$ \\
\hline Overweight ${ }^{\mathrm{e}}$ (yes = 1/ no =0) & 1.52 & $1.21-1.93$ & 1.51 & $1.18-1.92$ \\
\hline History of trauma/ injury ${ }^{f}(y e s=1 /$ no $=0$ ) & 1.81 & $1.32-2.49$ & 1.88 & $1.36-2.62$ \\
\hline Diabetes $^{9}($ yes $=1 /$ no $=0)$ & 1.87 & $1.27-2.77$ & 1.47 & $0.98-2.20$ \\
\hline
\end{tabular}

Odds ratios with $95 \%$ confidence intervals that do not have null value (shown in bold face) are statistically significant $(P<0.05)$;

${ }^{a} 18-34 y=$ coded as $1,35-54 y=$ coded as 2, 55-99 $y=$ coded as 3;

${ }^{\mathrm{b}}$ No education $=1$, any primary $=2$, any secondary $=3$, above higher secondary $=4$

${ }^{\mathrm{C}}$ Fifth quintile versus rest of MET minutes per week categories;

${ }^{\mathrm{d}}$ See Table 1 for groups

${ }^{\mathrm{e}}$ Body mass index $\geq 25.0 \mathrm{~kg} / \mathrm{m}^{2}$

fPhysical trauma during last 12 months that needed medical treatment with or without residual damage, e.g., injuries due to accidents while travelling by road, trauma during occupational works while working in farming lands or factories, physical assault, etc

${ }^{9}$ Defined as random capillary glucose level $>=11.1$ or medication for diabetes

rapid urbanization, transition to sedentary work and weight gain might also have contributed [61]. Contribution of related psychological factors like stress also remains to be studied in future [62].

Knee osteoarthritis (7.3\%) was the second commonest rheumatic disorder. It may be related to more knee usage in our community during occupational and household chores, leisure and prayers [63]. Repetitive joint use and working in squatting position for prolonged time may be responsible for the high prevalence of knee osteoarthritis among homemakers, cultivators and manual vehicle (cycle rickshaw, cycle van, etc.) pullers. Climbing high stairs in urban areas might also be linked. This prevalence was lower than that of the urban Iran $15.3 \%$ [52] and higher than that of India (4.42\%) [21] and Lebanon 3\% [64]. Female gender, obesity and previous knee injury are recognized major risk factors of knee osteoarthritis. A study comparing risk factors among some of these countries might shed light on the cause of difference of the difference in the modifiable risk factors of knee osteoarthritis in the Asian countries.

Soft tissue rheumatism was in the third position in order of prevalence in our study. It had occupied the topmost position in COPCORD studies carried out among the Australian aborigines [65], Filipino [12] and Indonesian [13] rural studies. They have constituted major bulk of the MSK conditions in other Asia-Pacific COPCORD studies. Its high prevalence in the developing countries and in the rural communities may be explained by ergonomically inconvenient workerworkstation interface these settings [66]. In the present series, there was a big gender difference in the prevalence of soft tissue rheumatism. It may be explained by the inclusion of fibromyalgia (26 out of 70), a disease occurring exclusively in women, in this category of MSK conditions.

The prevalence of rheumatoid arthritis was $1.6 \%$, women had significantly higher prevalence $(2.4 \%)$ compared to men $(0.7 \%)$. The prevalence reported in the previous Bangladesh COPCORD survey of 2005 was $0.9 \%$ [23]. Our current finding is close to that of Cuba (1.2\%) [27] and Mexico (1.6\%) [26]. The most contrasting findings have been reported from nearby Asian countries: India (0.5\%) [21], Pakistan (0.6\%) [18, 20], Thailand (0.1\%) [19] and Malaysia (0.2\%) [57]. The higher prevalence in our survey may be partly explained by the adoption of American College of Rheumatology/ European League Against Rheumatism (ACR/EULAR) 2010 classification criteria which has a higher sensitivity (97\%) [34]. Prevalence of spondyloarthritis was $1.2 \%$, which was also higher than in other COPCORD studies. Again, this might be attributed partly to the adoption of the new ASAS classification criteria which has a higher sensitivity (83\%) [35].

\section{Factors related to rheumatic conditions}

Education was a better discriminator than the wealth indices for MSK disorders in our sample. Educational 
achievement has been reported to have better rheumatoid arthritis outcome concerning pain and function [67]. Occupations demanding heavy physical work like homemaking, cultivation and rickshaw pulling had higher rates of complaints. Musculoskeletal problems were more common in subjects who performed heavy physical work and, particularly, in those in jobs that involve kneeling and squatting [68]. High BMI $(\geq 25)$ was associated with higher musculoskeletal pain. Overweight and obese subjects had higher prevalence of pain in joints, knees, limbs and lower leg compared with normal weight subjects $[69,70]$. History of trauma, as we observed, is associated with MSK conditions such as rheumatoid arthritis [71]. Diabetic patients had higher burden of musculoskeletal manifestations [72]. Diabetes affects the musculoskeletal system in multiple ways such as favoring hyperostosis, impacting joint mobility, neuropathy and microvascular diseases. Epidemiological studies support that MSK conditions are somehow associated with insulin resistance. It is well-known that many MSK conditions like adhesive capsulitis of shoulder, trigger finger, carpal tunnel syndrome etc. occur more frequently in diabetics compared to the non-diabetics. The association of diabetes with MSK conditions in our sample, however, disappeared in the age and sex-adjusted logistic model. It may be explained by the fact that our sample size was not adequate for multivariate regression modeling.

\section{Disability}

In the current study the prevalence of functional disability was $24.8 \%$. In the urban Iran $(28.3 \%)$ the disability rate was close to this study [25]. The disability rates were a little lower in the earlier Bangladesh COPCORD survey (24\%) [23]. Our rates in both the studies are much higher than rural Philippines (1.8\%) [14] and rural Thailand (3\%) [19]. These large differences may partly be explained by differences in definitions and methodologies used to detect functional disability [23], social custom, differences in occupation and workplace environment.

\section{Limitations}

It was sometimes difficult to distinguish closely resembling conditions with the field epidemiological definitions. Most of the recognized classification criteria demand some investigations which were sometimes not possible due to lack of facilities in nearby locations and subjects' unwillingness to travel long distance. For example, ASAS classification criteria for axial spondyloarthritis demand a few mandatory investigations [40], which were not possible in some cases. The sample size estimation for this survey was based on prevalence of MSK conditions combined. Therefore, caution has to be exerted in interpreting the results of individual conditions (specially the rare ones) especially when they are split in to four reporting domains.

Strengths: We used rheumatology residents as research physicians who had received extensive training before their deployment to the field. Most diagnoses made by them were double checked by the investigators. One visit of the investigators to each PSU was mandatory to validate their diagnosis and sort out confusing cases.

\section{Conclusions}

Three in ten Bangladeshi adults suffer from MSK conditions. Low educational status, overweight and history of trauma are the factors to be targeted for interventions. This nationally representative survey warrants health system's greater attention for addressing the challenges of pain and disabilities associated with MSK conditions. Further studies are needed to estimate the impact of this group of conditions particularly addressing related disabilities and loss of works.

\section{Abbreviations \\ ACR: American College of Rheumatology; ASAS: Assessment of SpondyloArthritis international Society; BMI: Body mass index; CASP AR: CIASsificationcriteria for Psoriatic ARthritis; Cl: Confidence interval; COPCORD: Community Oriented Programme for Control of Rheumatic Disorders; DALY: Disability adjusted life years; EULAR: European League Against Rheumatism Collaborative Initiative; LMIC: Low- and middle-income countries; MET: Metabolic equivalent task; MSK: Musculoskeletal; OA: Osteoarthritis; OR: Odds ratio; PSU: Primary sampling unit; STEPS: Step- wise surveillance; WHO: World Health Organization; YLD: Years of life with disability}

\section{Acknowledgements}

We express our heartfelt gratitude to Professor Minhaj Rahim Choudhury and Professor Md Nazrul Islam, Department of Rheumatology, Bangabandhu Sheikh Mujib Medical University for their support and guidance. The support of Mr. Md. Hasanuzzaman Khan of WHO Bangladesh for data management and analysis was crucial. We extend special thanks to Mr. Reazwanul Haque Khan, Ms. Suraiya Akter and Ms. Khaleda Akter for administrative and secretarial support for conducting the study and writing the manuscript.

\section{Authors' contributions}

AZAQ developed questionnaire and the manual, implemented the survey, analyzed data, interpreted the result and prepared the first draft of the manuscript. MMZ designed the study, guided data analysis, interpreted result critically, reviewed and revised the manuscript critically. MRB developed the manual, trained field team, monitored field implementation and reviewed the literature and prepared the reference list. MMR, IP, BBD, ShAH, SP, AS, and MR implemented the survey in their respective divisions, took part in quality assurance, guided the research physicians in making diagnosis of doubtful cases, and reviewed the manuscript. SyAH jointly designed the study, guided field execution, revised the manuscript critically and approved submission. He is the guarantor of data. All authors have read and approved the manuscript.

\section{Funding}

This work was supported by World Health Organization, Bangladesh (Agreement Reference: SEBAN140895). WHO, as a part of its mandate to strengthen national research capacity, provided technical guidance in designing, implementing, analyzing data and writing the report. However, it does not have any influence on the results. 


\section{Availability of data and materials}

All data generated or analyzed during this study are included in this published article [and its supplementary information files].

\section{Ethics approval and consent to participate}

Ethical guidelines as outlined by the Declaration of Helsinki were followed throughout the study. Ethical clearance was obtained from the Institutional Review Board of Bangabandhu Sheikh Mujib Medical University. Concurrence has been obtained from the local health authorities and elected representatives of the local government prior to data collection. Written (or thumb impression if unable to write) consent was obtained from the respondents in Bangla as per the ethical clearance guidelines.

\section{Consent for publication}

Not applicable.

\section{Competing interests}

The authors declare no competing interests. The authors alone are responsible for views expressed in this article and they do not necessarily represent the views, decisions or policies of the institutions with which they are affiliated.

\section{Author details}

'Department of Rheumatology, Bangabandhu Sheikh Mujib Medical University, Dhaka, Bangladesh. ${ }^{2}$ WHO Bangladesh, 10 Gulshan Avenue, Road Number 5, Gulshan 1, Dhaka 1212, Bangladesh. ${ }^{3}$ Department of Medicine, Dhaka Medical College, Dhaka, Bangladesh. ${ }^{4}$ Department of Medicine, Sylhet Women's Medical College, Sylhet, Bangladesh. ${ }^{5}$ Department of Medicine, Rangpur Medical College, Rangpur, Bangladesh. 'Department of Medicine, Khulna Medical College, Khulna, Bangladesh. ${ }^{7}$ Department of Medicine, Chittagong Medical College, Chittagong, Bangladesh. ${ }^{8}$ Department of Medicine, Rajshahi Medical College, Rajshahi, Bangladesh. ${ }^{9}$ Department of Medicine, Patuakhali Sadar Hospital, Patuakhali, Bangladesh.

\section{Received: 8 May 2020 Accepted: 5 October 2020}

\section{Published online: 16 December 2020}

\section{References}

1. Briggs AM, Woolf AD, Dreinhöfer K, Homb N, Hoy DG, Kopansky-Giles D, Åkesson K, March L. Reducing the global burden of musculoskeletal conditions. Bull World Health Organ. 2018. https://doi.org/10.2471/BLT.17. 204891.

2. Briggs AM, Cross MJ, Hoy DG, Sànchez-Riera L, Blyth FM, Woolf AD, March L. Musculoskeletal health conditions represent a global threat to healthy aging: a report for the 2015 World Health Organization world report on ageing and health. Gerontologist. 2016. https://doi.org/10.1093/geront/ gnw002.

3. Nüesch E, Dieppe P, Reichenbach S, Williams S, Iff S, Jüni P. All cause and disease specific mortality in patients with knee or hip osteoarthritis: population based cohort study. Br Med J. 2011. https://doi.org/10.1136/bmj. d1165.

4. Williams A, Kamper SJ, Wiggers JH, O'Brien KM, Lee H, Wolfenden L, Yoong SL, Robson E, McAuley JH, Hartvigsen J, Williams CM. Musculoskeletal conditions may increase the risk of chronic disease: a systematic review and meta-analysis of cohort studies. BMC Med. 2018. https:/doi.org/10.1186/ s12916-018-1151-2.

5. Duffield SJ, Ellis BM, Goodson N, Walker-Bone K, Conaghan PG, Margham T, Loftis T. The contribution of musculoskeletal disorders in multimorbidity: implications for practice and policy. Best Pract Res Clin Rheumatol. 2017. https://doi.org/10.1016/j.berh.2017.09.004.

6. Access Economics. Painful realities: the economic impact of arthritis in Australia in 2007. Melbourne: Access Economics; 2007. [Accessed 2 April 2020] Available from: https://arthritisaustralia.com.au/wordpress/wp-content/ uploads/2017/09/painful-realities-report-access-economics.pdf.

7. Clarke AM, Symmons DPM. The burden of rheumatic disease. Medicine. 2006. https://doi.org/10.1053/.jmpmed.2006.06.007.

8. Arthritis and Osteoporosis Victoria. A problem worth solving. Elsternwick. Arthritis and Osteoporosis. Victoria 2013 [Accessed 2 Apr 2020] Available from: https://www.msk.org.au/wp-content/uploads/2018/07/APWS.pdf.

9. Sebbag E, Felten R, Sagez F, Sibilia J, Devilliers H, Arnaud L. The world-wide burden of musculoskeletal diseases: systematic analysis of the World Health
Organization burden of diseases database. Ann Rheum Dis. 2019. https:// doi.org/10.1136/annrheumdis-2019-215142.

10. Brennan-Olsen SL, Cook S, Leech MT, Bowe SJ, Kowal P, Naidoo N, Ackerman IN, Page RS, Hosking SM, Pasco JA, Mohebbi M. Prevalence of arthritis according to age, sex and socioeconomic status in six low and middle income countries: analysis of data from the World Health Organization study on global AGEing and adult health (SAGE) wave 1. BMC Musculoskelet Disord. 2017. https://doi.org/10.1186/s12891-017-1624-z.

11. Grabauskas V. World Health Organization perspective. J Rheumatol. 1983; 10(Supplement):5-6 PMID: 6582272.

12. World Health Organization.n.d. WHO-ILAR community oriented programs on rheumatic diseases. Report by H. A. Valkenburg. NCD/OND/RH/WP/81.5.

13. Manahan L, Caragay R, Muirden KD, Allander E, Valkenburg HA, Wigley RD. Rheumatic pain in a Philippine village. AWHO-ILAR COPCORD study. Rheumatol Int. 1985. https://doi.org/10.1007/bf00541515.

14. Wigley RD, Manahan L, Muirden KD, Caragay R, Pinfold B, Couchman KG, Valkenburg HA. Rheumatic disease in a Philippine village II: a WHO-ILARAPLAR COPCORD study, phases II and III. Rheumatol Int. 1991. https://doi. org/10.1007/BF00332554.

15. Darmawan J, Valkenburg HA, Muirden KD, Wigley RD. Epidemiology of rheumatic diseases in rural and urban populations in Indonesia: a World Health Organization International League Against Rheumatism COPCORD study, stage I, phase 2. Ann Rheum Dis. 1992. https://doi.org/10.1136/ard.51. 4.525 .

16. Darmawan J, Valkenburg HA, Muirden KD, Wigley RD. The epidemiology of rheumatoid arthritis in Indonesia. Br J Rheumatol. 1993. https://doi.org/10. 1093/rheumatology/32.7.537.

17. Darmawan J, Muirden KD, Valkenburg HA, Wigley RD. The prevalence of soft tissue rheumatism in Indonesia - a WHO-ILAR COPCORD study. Rheumatol Int. 1995. https://doi.org/10.1007/BF00302129.

18. Dans LF, Tankeh-Torres S, Amante CM, Penserga EG. The prevalence of rheumatic diseases in a Filipino urban population: a WHO-ILAR COPCORD study. J Rheumatol. 1997;4:1814-9 PMID: 9292809.

19. Chaiamnuay P, Darmawan J, Muirden KD, Assawatanabodee P. Epidemiology of rheumatic disease in rural Thailand: a WHO-ILAR COPCORD study. J Rheumatol. 1998;25:1382-7 PMID: 9676773.

20. Farooqi A, Gibson T. Prevalence of major rheumatic disorders in the adult population of North Pakistan. Br J Rheumatol. 1998. https://doi.org/10.1093/ rheumatology/37.5.491.

21. Chopra A, Patil J, Billampelly V, Ralwani J, Tandale HS. Prevalence of rheumatic diseases in a rural population in western India: a WHO-ILAR COPCORD study. J Assoc Phys India. 2014;9:240-6 PMID: 11225138.

22. Minh Hoa TT, Darmawan J, Chen SL, Van Hung N, Thi Nhi C, Ngoc An T. Prevalence of the rheumatic diseases in urban Vietnam: a WHO- ILAR COPCORD study. J Rheumatol. 2003;30:2252-6 PMID: 14528525.

23. Haq SA, Darmawan J, Islam MN, Uddin MZ, Das BB, Rahman F, Chowdhury MAJ Alam MN, Mahmud TAK, Chowdhury MR, Tahir M. Prevalence of rheumatic diseases and associated outcomes in rural and urban communities in Bangladesh: a COPCORD Study. J Rheumatol. 2005;32:348-53 PMID: 15693098.

24. Davatchi F, Tehrani Banihashemi A, Gholami J, Faezi ST, Forouzanfar MH, Salesi M, Karimifar M, Essalatmanesh K, Barghamdi M, Noorolahzadeh E, Dahaghin S, Rasker JJ. The prevalence of musculoskeletalcomplaints in a rural area in Iran: a WHO-ILAR COPCORD Study (stage I, rural study) in Iran. Clin Rheumatol. 2009. https://doi.org/10.3899/jrheum.080675.

25. Moghimi N, Davatchi F, Rahimi E, Saidi A, Rashadmanesh N, Moghimi S, Ghafori H, Zandi P, Ahmadi N, Ghafori H, Moghimi M, Hajiheshmati M. WHO-ILAR COPCORD study (stage 1, urban study) in Sanadaj, Iran. Clin Rheumatol. 2015. https://doi.org/10.1007/s10067-013-2431-0.

26. Pelaez-Ballestas I, Sanin LH, Moreno-Montoya J, Alvarez-Nemegyei J, BurgosVargas R, Garza-Elizondo M, Rodriguez-Amado J, Goycochea-Robles MV, Madariaga M, Zamudio J, Santana N, Cardiel MH. Epidemiology of the rheumatic diseases in Mexico. A study of 5 regions based on the COPCORD methodology. J Rheumatol. 2011. https://doi.org/10.38899/jrheum.100951.

27. Llerena GA, Toledano MG, Martínez AA, Otero ZAG, Varela JA, Cardiel MH. Prevalence of musculoskeletal complaints and disability in Cuba. A community-based study using the COPCORD core questionnaire. Clin Exp Rheumatol. 2000;18(6):739-42. 11138339.

28. Institute of Health Metrics and Evaluation. Top 10 causes of years lived with disability (YLDs) in 2017 and percent change, 2007-2017, all ages, number, Bangladesh. [Accessed 2 April 2020]. Available from: http://www.healthdata. org/bangladesh 
29. Zaman MM, Rahman M, Rahman M, Bhuiyan MR, Karim M, Chowdhury MJ. Prevalence of risk factors for non-communicable diseases in Bangladesh: results from STEPS survey 2010. Indian J Public Health. 2016. https://doi.org/ 10.4103/0019-557X.177290.

30. Bangladesh Bureau of Statistics. Population and housing census 2011, preliminary result. Dhaka: Bangladesh Bureau of Statistics; 2011. Accessed 2 Apr 2020. http://bbs.portal.gov.bd.

31. Kish L. A procedure for objective respondent selection within the household. J Am Stat Assoc. 1949. https://doi.org/10.1080/01621459.1949. 10483314.

32. Community Oriented Programme for Control of Rheumatic Diseases. Tools/ Questionnaire [Accessed 2 April 2020]. Available from: http://www.copcord. org.

33. Islam MA. Cultural adaptation of COPCORD core English questionnaire and re-estimation of prevalence of rheumatic disorders in rural community of Bangladesh. MD thesis. Dhaka: Bangabandhu Sheikh Mujib Medical University; 2012

34. Aletaha D, Neogi T, Silman AJ, Funovits J, Felson DT, Bingham CO, Birnbaum NS, Burmester GR, BykerkVP CMD, Combe B, Costenbader KH, Dougados M, Emery P, Ferraccioli G, Hazes JM, Hobbs K, Huizinga TW, Kavanaugh A, Kay J, Kvien TK, Laing T, Mease P, Menard HA, Moreland LW, Naden RL, Pincus T, Smolen JS, Stanislawska-Biernat E, Symmons D, Tak PP, Upchurch KS, JVF W, Hawker G. 2010 rheumatoid arthritis classification criteria: an American College of Rheumatology/ European League Against Rheumatism collaboration initiative. Ann Rheum Dis. 2010. https://doi.org/ 10.1136/ard.2010.138461

35. Rudwaleit M. New classification criteria for spondyloarthritis. Int J Adv Rheumatol. 2010a:8:1-7.

36. Hochberg MC. Updating the American College of Rheumatology revised criteria for the classification of systemic lupus erythematosus. Arthritis Rheum. 1997a. https://doi.org/10.1002/art.178040092835.

37. Altman R, Asch E, Bloch D, Bole G, Borenstein D, Brandt K, Christy W, Cooke TD, Greenwald R, Hochberg M, Howell D, Kaplan D, Koopman W, Longley S, Mankin H, McShane J, Medsger T, Meenan R, Mikkelsen W, Moskowitch R, Murphy W, Rothschild B, Segal M, Sokoloff L, Wolfe F. Development of criteria for the classification and reporting of osteoarthritis. Classification of osteoarthritis of the knee. Diagnostic and Therapeutic Criteria Committee of the American Rheumatism Association. Arthritis Rheum. 1986. https://doi. org/10.1002/art.1780290816.

38. Altman R, Alarcon G, Appelrouth D, Bloch D, Borenstein D, Brandt K, Brown C, Cooke TD, Daniel W, Gray R, Greenwald R, Hochberg M, Howell D, Ike R, Kapila P, Kaplan D, Koopman W, Longley S, McShane J, Medsger T, Michel B, Murphy W, Osial T, Ramsey-Goldman R, Rothschild B, Stark K, Wolfe F. The American College of Rheumatology criteria for the classification and reporting of osteoarthritis of the hand. Arthritis Rheum. 1990. https://doi. org/10.1002/art.1780331101.

39. Aletha D, Neogi T, Silman AJ, Funovits FDT, Bingham CO, Birnbaum NS, Bermester GR, Bykerk VP, Cohen MD, Combe B, Costenbader KH, Dougados M, Emery P, Ferraccioli G, Hazes JMW, Hobbs K, Huizinga TWJ, Kavanaugh A, Kay J, Kvien TK, Laing T, Mease P, Menard HA, Moreland LW, Naden RL, Pincus T, Smolen JS, Stanislawska-Biernat E, Symmons D, Tak PP, Upchurch KS, Vencovsky J, Wolfe F, Hawkwer G. Rheumatoid arthritis classification criteria: an American College of Rheumatology/European League Against Rheumatism Collaborative Initiative. Arthritis Rheum. 2010;2010. https://doi. org/10.1002/art.27584.

40. Rudwaleit M. New approaches to diagnosis and classification of axial and peripheral spondyloarthritis. Curr Opin Rheumatol. 2010b. https://doi.org/10. 1097/BOR.0b013e32833ac5cc.

41. van der Linden S, Valkenburg HA, Cats A. Evaluation of diagnostic criteria for ankylosing spondylitis (A Proposal for Modification of the New York Criteria). Arthritis and Rheumatism. 1984. https://doi.org/10.1002/art. 1780270401.

42. Taylor W, Gladman D, Helliwell P, Marchesoni A, Mease P, Mielants H, CASP AR Study Group. Classification criteria for psoriatic arthritis. Arthritis Rheum. 2006. https://doi.org/10.1002/art.21972.

43. Peat G, Thomas E, Duncan R, Wood L, Hay E, Croft P. Clinical classification criteria for knee osteoarthritis: performance in the general population and primary care. Ann Rheum Dis. 2006. https://doi.org/10.1136/ard.2006.051482.

44. Hochberg MC. Updating the American College of Rheumatology Revised Criteria for the classification of systemic lupus erythematosus. Arthritis Rheum. 1997b. https://doi.org/10.1002/art.1780400928.
45. Reveille JD. Soft-tissue rheumatism: diagnosis and treatment. Am J Med 1997. https://doi.org/10.1016/s0002-9343(97)00413-0.

46. Islam N, Basak TB, Oudevoshaar, Ferdous N, Rasker JJ, Haq SA. Cross-cultural adaptation and validation of a Bengali Health Assessment Questionnaire for use in rheumatoid arthritis patients. Int J Rheum Dis. 2013. https://doi.org/ 10.1111/1756-185X.12032.

47. Bruce B, Fries JF. The Stanford health assessment questionnaire: a review of its history, issues, progress, and documentation. J Rheumatol. 2003;30:167-8 PMID: 12508408

48. Quintana R, Silvestre AM, Goni M, Garcia V, Mathern N, Jorfen M, Miljevic J, Dhair D, Laithe M, Conti S, Madauar F, Martin MC, Barrios MC, Nieto R, Prigione C, Sanabria A, Gervasoni V, Grabbe E, Gontero R, Pelaez-Ballestas I, Pons-Estel BA. Prevalence of musculoskeletal disorders and rheumatic diseases in the indigenous Qom population of Rosario, Argentina. Clin Rheumatol. 2016. https://doi.org/10.1007/s10067-016-3192-2.

49. WMA Declaration of Helsinki - ethical principles for medical research involving human subjects. [Cited on: 2020 Aug 29] Available from: https:// www.wma.net/policies-post/wma-declaration-of-helsinki-ethical-principlesfor-medical-research-involving-human-subjects/.

50. Cisternas MG, Murphy LB, Yelin EH, Foreman AJ, Pasta DJ, Helmick CG. Trends in medical care expenditures of US adults with arthritis and other rheumatic conditions 1997 to 2005. J Rheumatol, DOI. 2009. https://doi.org/ 10.3899/jrheum.081068.

51. Yelin E, Murphy L, Cisternas MG, Foreman AJ, Pasta DJ, Helmick CG. Medical care expenditures and earnings losses among persons with arthritis and other rheumatic conditions in 2003, and comparisons with 1997. Arthritis Rheum. 2007. https://doi.org/10.1002/art.22565.

52. Davatchi F, Jamshidi AR, Banihashemi AT, Gholami J, Forouzanfar MH, Akhlaghi M, Barghamdi M, Noorolahzadeh E, Khabazi AR, Salesi M, Salari AH, Karimifar M, Essalat-Manesh K, Hajialiloo M, Soroosh M, Farzad F, Moussavi HR, Samadi F, Ghaznavi K, Asgharifard H, Zangiabadi AH, Shahram F, Nadji A, Akbarian M, Gharibdoost F. WHO-ILAR COPCORD study (stage I, urban study) in Iran. J Rheumatol. 2008;35:1384-90 PMID: 18464299.

53. Lotters F, Burdorf A, Kuiper J, Miedema H. Model for the work-relatedness of low-back pain. Scand J Work Environ Health. 2003. https://doi.org/10.5271/ sjweh.749.

54. Koley S, Singh G, Sandhu R. Severity of disability in elderly patients with low back pain in Amritsar, Punjab. Anthropologist. 2008. https://doi.org/10.1080/ 09720073.2008.11891060.

55. Lotfi A, Abdel-Nasser AM, Hamdy A, Omran AA, El-Rehany MA. Hypovitaminosis $D$ in female patients with chronic low back pain. Clin Rheumatol. 2007. https://doi.org/10.1007/s10067-007-0603-4.

56. Al-Awadhi AM, Olusi SO, Moussa M, Shehab D, Al-Zaid N, Al-Herz A, AlJarallah K. Musculoskeletal pain, disability and health-seeking behavior in adult Kuwaitis using a validated Arabic version of the WHO-ILARCOPCORD Core Questionnaire. Clin Exp Rheumatol. 2004;22:177-83 PMID: 15083885.

57. Veerapen K, Wigley RD, Volkenburg H. Musculoskeletal pain in Malaysia. A COPCORD survey. J Rheumatol. 2007;4:207-13 PMID: 17216688.

58. Limburska I, Gaździk TS, Zejda JE. Back pain in coal miners of anthracite coal-pilot study results. Med Pr. 1996;47:339-46 PMID: 8847980.

59. Stewart M, Latimer J, Jamieson M. Back extensor muscle endurance test scores in coal miners in Australia. J Occup Rehabil. 2003. https://doi.org/10. 1023/A:1022547714552.

60. Sarika S, Ozdolap S, Gümüştasş S, Koç U. Low back pain and lumbar angles in Turkish coal miners. Am J Ind Med. 2007. https://doi.org/10.1002/ajim. 20417.

61. Nagasu M, Sakai $K$, Ito A, Tomita S, Temmyo $Y$, Ueno M, Shigeji M. Prevalence and risk factors for low back pain among professional cooks working in school lunch services. BMC Pub Health. 2007. https://doi.org/10. 1186/1471-2458-7-171.

62. Vindigni D, Walker BF, Jamison JR, Da Costa C, Parkinson L, Blunden S. Low back pain risk factors in a large rural Australian Aboriginal community. An opportunity for managing co-morbidities? Chirop Osteopat. 2005. https:// doi.org/10.1186/1746-1340-13-21.

63. Chopra A, Abdel-Nasser A. Epidemiology of rheumatic musculoskeletal disorders in the developing world. Best Pract Res Clin Rheumatol. 2008. https://doi.org/10.1016/j.berh.2008.07.001.

64. Chaaya M, Slim ZN, Habib RR, Arayssi T, Dana R, Hamdan O, Assi M, Issa Z, Uthman I. High burden of rheumatic diseases in Lebanon: a COPCORD study. Int J Rheum Dis. 2012. https://doi.org/10.1111/j.1756185X.2011.01682.x. 
65. Minaur N, Sawyers S, Parker J, Darmawan J. Rheumatic disease in an Australian Aboriginal Community in North Queensland, Australia. A WHOILAR COPCORD Survey. J Rheumatol. 2004;31:965-72 PMID: 15124258.

66. Schierhout GH, Meugerr JE, Btidge RS. Work related musculoskeletal disorders and ergonomic stressors in South Africa work force. Occup Environ Med. 1995. https://doi.org/10.1136/oem.52.1.46

67. Jiang X, Sandberg MEC, Saevarsdottir S, Klareskog L, Alfredsson L, Bengtsson C. Higher education is associated with a better rheumatoid arthritis outcome concerning for pain and function but not disease activity: results from the EIRA cohort and Swedish rheumatology register. Arthritis Res Ther. 2015. https://doi.org/10.1186/s13075-015-0836-6.

68. Kar SK, Dhara PC. An evaluation of musculoskeletal disorder and socioeconomic status of farmers in West Bengal, India. Nepal Med Coll $\rfloor$. 2007;9:245-9 PMID: 18298013.

69. Bihari V, Kesavachandran C, Pangtey BS, Srivastava, Mathur N Musculoskeletal pain and its associated risk factors in residents of National Capital Region. Indian J Occup Environ Med. 2011. https://doi.org/10.4103/ 0019-5278.90375.

70. Rogers MW, Wilder FV. The association of BMl and knee pain among persons with radiographic knee osteoarthritis: a cross-sectional study. BMC Musculoskelet Disord. 2008. https://doi.org/10.1186/1471-2474-9-163.

71. Al-Allaf AW, Sanders PA, Ogston SA, Marks JS. A case-control study examining the role of physical trauma in the onset of rheumatoid arthritis. Rheumatology. 2001. https://doi.org/10.1093/rheumatology/40.3.262

72. Serban AL, Udrea GF. Rheumatic manifestations in diabetic patients. J Med Life. 2012;5:252-7.

\section{Publisher's Note}

Springer Nature remains neutral with regard to jurisdictional claims in published maps and institutional affiliations.

Ready to submit your research? Choose BMC and benefit from:

- fast, convenient online submission

- thorough peer review by experienced researchers in your field

- rapid publication on acceptance

- support for research data, including large and complex data types

- gold Open Access which fosters wider collaboration and increased citations

- maximum visibility for your research: over $100 \mathrm{M}$ website views per year

At $\mathrm{BMC}$, research is always in progress.

Learn more biomedcentral.com/submissions 